\title{
Communication Strategies and Branding Attempts of Selected Countries Created upon the Disintegration of the Former Yugoslavia
}

\author{
Božo Skoko \\ University of Zagreb, Faculty of Political Science, Croatia \\ e-mail: bozo.skoko@fpzg.hr
}

\begin{abstract}
This article analyzes the attempts of four countries created upon the disintegration of the former Yugoslavia - Croatia, Slovenia, Bosnia and Herzegovina and Serbia - to use communication as a tool for establishing themselves as distinct travel destinations and for creating attractive brands in the international political and economic markets. The paper focuses particularly on the analysis of the communication and promotion approaches, and concepts and strategies used by these countries in terms of the processes behind the aims outlined in the preceding sentence. The level of success of each country, as regards the subject matter of this article, is determined for the purpose of the analysis in question, by the best known brand perception surveys. The paper also analyzes the disintegration of Yugoslavia in the context of the newlycreated countries' attempts to establish themselves internationally and compares their approaches to developing their brands and the models they are using for it. The countries in question are focused on tourism promotion. In these countries we see a tendency towards ignoring other aspects of branding. None of the analyzed countries have introduced the systematic management of their brands due to the fact that the process of brand development is obstructed by unresolved political issues or a failure of their politicians and ordinary citizens to understand the advantages of branding. Slovenia, according to the criteria used in this analysis, has adopted more efficient practices than the other three countries covered in this paper but it is important to stress that Croatia ranks first when it comes to tourism branding. The paper suggests that the importance of country branding has not yet been fully appreciated in Croatia, Slovenia, Bosnia and Herzegovina and Serbia and that no integral branding concepts are being used, despite sporadic attempts undertaken by the mentioned countries.
\end{abstract}

Key words: country, branding, public relations, Croatia, Slovenia, Bosnia and Herzegovina, Serbia. 


\section{Introduction}

The process of the disintegration of Yugoslavia was tightly tied in with other local and global processes. It started in 1991 when Slovenia, Croatia, Macedonia and Bosnia and Herzegovina declared independence, but the spark that ignited the dormant desire for independence in the mentioned countries was the collapse of the bipolar world order brought on by the political and economic instability in the Union of Soviet Socialist Republics (USSR) and the collapse of Communism in Central and Eastern Europe. After 46 years of Communist rule the constituent republics of the SFRY were free to go their own way. As a result, the non-aligned Yugoslavia lost its geostrategic importance that had earlier ensured abundant support from both East and West. Jović (2003:487) holds that a number of factors caused the disintegration of Yugoslavia, central among them being the disintegration of the ideological consensus within the Yugoslav political elites, which had taken place in the form of a gradual, lengthy process that had led to the disintegration of the state institutions themselves. Steindorff (2006:207) is of the opinion that the death of Josip Broz Tito (Communist leader and president of Yugoslavia from 1945 to 1980) was a symbolical turning point that marked the beginning of the state crisis in Yugoslavia. Tito's authority had been undisputed and his cult of personality was one of the decisive integrating elements of the Socialist Federal Republic of Yugoslavia. The position and powers he held as lifetime president were transferred, after his death, to the collective eight-member presidency (consisting of one representative from each republic and autonomous province). The president of this collective body would be elected from among them for a one-year mandate. The collective presidency and the principle that all decisions were to be made by a majority vote were supposed to prevent the hegemony of any one ethnic group over the others and secure the viability of the SFRY (Skoko, 2010:25). Also, in the late 1970s, Yugoslavia started experiencing a permanent economic crisis as a result of its accumulated foreign debt, inadequate innovation and efficiency of its companies, and inefficient functioning of its state self-management institutions (Steindorff, 2010:25). However, the pivotal development that pushed the country towards disintegration and war was the rise of Slobodan Milošević as Serbia's leader. He began materializing the tendencies of Serbian nationalist elites. It has to be noted that the 1991-1992 negotiations of the presidents of six Yugoslav republics (Slovenia, Croatia, Bosnia and Herzegovina, Montenegro, Serbia and Macedonia) on the reorganization of the Yugoslav federation failed, despite the international community's strong support to the federal government's efforts to carry out reforms and turn the SFRY into a democratic federation with a market economy (Silber and Little, 1997:147-149). Slovenia and Croatia shared the opinion that Yugoslavia should be transformed into a confederation. They also insisted that every constituent republic of the SFRY had the right to declare independence under the provisions of the 1974 Constitution. Serbia and Montenegro were in favour of maintaining the existing arrangement. However, they asserted that if any one republic seceded, ethnic groups living in them (primarily referring to the Serbs living in Croatia and Bosnia and Herzegovina) had the right to self-determination (Silber and Little, 1997:147-149). Led by Serbian president Slobodan Milošević and supported by the Yugoslav People's Army, Serbia and Montenegro launched an aggression against their western neighbours in order to create a "Greater Serbia". 
The disassociation of Yugoslav republics was accompanied by six wars: the Ten-Day War in Slovenia in July 1991; the Croatian War of Independence (1991-1995); the Bosnian War (1992-1995); the Kosovo War and NATO's bombing of Serbia in 1999; and the 2001 Insurgency in the Republic of Macedonia. The cumulative result of the wars was 300,000 deaths, massive destruction, hundreds of thousands of displaced persons and refugees and a collapsed economy. According to Bilandžić (2000:46), all the ideologies supporting the idea of a common south Slav political entity disappeared in these wars: from the Pan-Slavism and Yugoslavism of the $19^{\text {th }}$ and $20^{\text {th }}$ centuries to the ideology of "brotherhood and unity", aggressively promoted by the Yugoslav authorities and media, creating an elaborate iconography based on the premise that Yugoslavia was a bastion against the hegemony of any given, past, present or future, great power.

Taken by surprise by the outbreak of hostilities in Yugoslavia, certain circles in the international community tried to save the integrity of Yugoslavia at all costs, justifying the effort by the fact that Yugoslavia was perceived in a relatively positive light in the West and was generally deemed a successful socialist experiment.

Bilandžić (2000:43) claims there was no other such small area in Europe with so many differences in levels of development. For example, the differences between some of the republics and autonomous provinces in socialist Yugoslavia were greater than those between the most developed and least developed European countries. These different starting positions were later reflected in the development of the newly created countries.

Slovenia was the most developed Yugoslav republic. Also, it suffered negligible damage in its ten-day war against the Yugoslav People's Army (YPA). After this short war, the country experienced rapid economic growth. Slovenia became the EU member state together with the other East European states that joined the Union in the first wave of enlargement in 2004. As the second most developed Yugoslav republic, Croatia is still second only to Slovenia in terms of political and economic standards in relation to the other countries of the former Yugoslavia. It has to be pointed out that Croatia fought for its independence against the YPA and rebel Serbs for five years and the loss of life and material destruction sustained in the war significantly hampered its development. Only in 1997 did it manage to re-establish constitutional order throughout its entire territory. Croatia joined the European Union in 2013.

In the late 1980s in most republics of the SFRY there was a marked tendency towards liberalisation in the political, economic and social spheres. On the other hand, Serbia, led by Slobodan Milošević, experienced a dramatic drift towards reactionism and irredentism. It is a historic fact that Serbia was responsible for the violent disintegration of the former Yugoslavia. The country still inefficiently grapples with the issue of war guilt, as if Serbian officialdom cannot decide whether to accept the responsibility for the war or lament the fact that it suffered an ignominious defeat in every war it waged after the breakup of the SFRY. Violent domestic politics (with ultranationalist parties - radicals and socialists - winning elections), provoking wars 
and causing an implosion of its territory, have marked the past fifteen years in Serbia (Vurušić, 2008). After the disintegration of Yugoslavia, Serbia and Montenegro remained in a joint state until the latter opted for independence in 2006. Two years later, Serbia formally lost Kosovo - a former autonomous province in Yugoslavia when the international community recognized its independence despite Serbia's and Russia's opposition.

The path to independence was the hardest for Bosnia and Herzegovina. Even today, it is still an undefined and struggling country consisting of two entities and three peoples, (Bosniaks, Croats and Serbs) each with different interests and expectations. Although elections on all three levels of government take place at regular intervals, in reality, the country is governed by the High Representative appointed by the international community, who has the right to veto all the decisions of the government and parliament and the right to replace officials. The independence of Bosnia and Herzegovina was declared in 1991 by Bosniaks and Croats only. Supported by the Yugoslav People's Army and following the agenda of Greater Serbia, the Bosnian Serbs rebelled in 1992. The aim of the rebellion was to force Bosnia and Herzegovina to cede a large portion of its territory to Serbia. The plan failed for two reasons: Bosniaks organized their own army and refused to give in and the international community - the US in particular - recognized Bosnia and Herzegovina and prevented its partition (Bilandžić, 2000:51). The signing of the Dayton Accord in 1995 ended the war, but the country was irrationally divided in two territorial entities - Federation of Bosnia and Herzegovina (where Bosniaks and Croats live) and Republic of Srpska (ethnically cleansed during the war and now populated mostly by Serbs). In reality, the two entities - plus Brčko District - function separately, with a very little consent regarding common interests of the state. At the same time, Croats in the Federation - as the smallest constituent nation - are not really able to control their own destiny because the government caters to the interests of the Bosniak majority. The war in Bosnia and Herzegovina was extremely brutal, with massive loss of life and property. The Srebrenica genocide - the largest individual atrocity in Europe after World War II is but one example of the savage, merciless and internecine nature of the war. There were armed conflicts between Serbs and Bosniaks, Serbs and Croats, Bosniaks and Croats, even Bosniaks and Bosniaks. The country still functions on ethnic principles instead of on political or social ones. Because of the failed economy, unemployment, inflation and general lack of social development, the country ranks far behind other transition countries. The unstable political and economic situation has reduced to a minimum its chances of joining the EU and NATO anytime soon. Still, in June 2008, Bosnia and Herzegovina signed the Stabilization and Association Agreement with the European Union, thus making its first step on the road to European integration (Skoko, 2010:36).

Seven new independent countries were created in the aftermath of the disintegration of the SFRY, each having tried in the past decades to attract international attention and establish itself as a tourist and economic brand. When they appeared on the map of Europe, most of them were complete unknowns because Yugoslavia (as the umbrella brand) had existed with different political systems for more than seven decades. As such, it was an established and recognizable country to many. Less known 
was the fact that the former Yugoslavia was a conglomerate of languages, cultures and religions, still containing elements from four different cultural spheres of the past: Byzantine, Islamic, Mediterranean and Central European. (Bilandžić, 2000:43) During most of their history, until the creation of Yugoslavia in 1918, its peoples constituted integral parts of different economic, political and cultural entities - primarily the Ottoman and Habsburg Empires (and Venice, in the case of Croatia). This is why the newly created countries insisted on resurrecting their national myths and legends with the aim of asserting their uniqueness and establishing an image of themselves as far removed as possible from the ones once aggressively promoted by the Yugoslav authorities. The results were mixed. Encumbered by the legacy of a common, supraethnic, and supranational identity, one that had been systematically imposed on them for half a decade, the newly created countries found that they could not break away overnight from the cultural and social shackles of the past in terms of how they were perceived by the rest of the world. In that regard, the wars in the former Yugoslavia went a long way toward preventing the countries created by the breakup of Yugoslavia to establish quickly a positive and unique image of them in the world.

This is why all the countries that emerged from the break-up of Yugoslavia conducted their own separate communication and promotion efforts, determined by political, social and economic circumstances. Undoubtedly, in doing so, they used the global branding experiences and tried to adapt them to their needs. The purpose of this article is to analyze the specific qualities of individual approaches of four exYugoslav countries and to evaluate their attempts to establish themselves as tourist, economic and cultural brands. The analysis will focus on four of these newly created countries - Slovenia, Croatia, Bosnia and Herzegovina and Serbia. The reason behind the choice is simple: the development of all four countries has been marred, to a lesser or higher degree, by war and all four countries have strived to create a new identity for themselves. As previously mentioned, all four countries have used different approaches and methods based on their respective circumstances, but the issue under examination in this work is to what extent they complied with professional branding standards. Based on that examination the purpose of this work is twofold: first, it will try to recognise and categorise the models and approaches developed by the countries in question in terms of their efforts to establish new identities, and second, it will attempt to recognise and categorise the types of impact the approaches and methods in question have garnered and levels of success they have achieved.

\section{Branding of transition countries in perspective}

While older countries enjoy well-established national images at home and abroad, the past century has seen the emergence of roughly 100 new nations, which face a double challenge. They are challenged first with crystallizing a coherent national image within the domestic realm. Secondly, states carry the burden of transmitting a positive country image to the global community (Saunders, 2012:51). In this sense, former Communist states faced specific challenges: identities of individual countries and nations had often been suppressed within multinational communities and the image of the entire Communist bloc was very negative in the West. 
One of the most damaging effects of Communism was the way in which it destroyed the national identity and the nation brands of the countries within the Soviet Union. By stopping the export of their national products and preventing people from travelling abroad, and in many other ways, the Soviet regime effectively deleted the old, distinctive European nation brands - Hungary, Poland, Czechoslovakia, Yugoslavia, Bulgaria, Romania, even Russia itself - that had been created and enriched over centuries of more benign rule. Most of these states are now working hard to rebuild their images and their identities, and it is a slow and painful process (Anholt, 2007: 118).

Many European countries in transition whose reality changed dramatically (e.g. due to the fall of Communism) started seeking ways to present their tourism potential, attract investment or develop their own brand for both the domestic market and export (Hall, 2004; Kaneva, 2012). After the fall of the Berlin Wall in 1989, many newly established countries in Central and Eastern Europe have relied on public relations to create new identities for themselves and communicate these identities to the rest of the world. Such examples are Estonia and the Czech Republic, which have successfully positioned themselves as independent, democratic and dynamic countries (Szondy, 2006:113). While they shared the fate of other countries in transition, the former Yugoslav republics had some specific experiences - like the war - that slowed down and substantially affected their efforts.

Precisely because of the wars in the former Yugoslavia, which were accompanied with the transition process, the states that emerged from the former Yugoslavia should be regarded as a specific phenomenon in relation to other transition countries.

Finding an identity became increasingly important for the newly formed nations in the aftermath of the armed conflicts in the former Yugoslavia. The fledgling states had no option but prioritise that particular aspect of their newly won independence. To them, the search for and recognition of the somewhat forgotten national identity meant a separation from their Yugoslav past and a return to their roots, history and traditions (Novčić and Štavljanin, 2015:266).

Volumes of literature and research on transition-country branding attempts have been published in recent years. In her book Branding Post-Communist Nations, Nadia Kaneva (2012) deals with the phenomenon of marketizing national identities in the "New Europe". She presents an overview of the research conducted on this phenomenon and analyzes the branding attempts of some Central and Eastern European countries and mistakes the countries in question made in the process. Namely, a number of critical studies look specifically at Central and Eastern Europe (CEE), where nation branding has proliferated particularly fast, and examine the challenges of national re-definition through branding in the post-communist context (Aronczyk, 2007; Baker, 2008; Dzenovska, 2005; Jansen, 2008; Kaneva, 2007, 2012; Vočić, 2008; Widler, 2007). The focus on the post-communist experience is motivated by the broader goal of contributing to the study of changes in the structure and relations of power, identification, and mediation that were enabled by the end of Communism 
(Kaneva, 2012:5). Some authors link branding attempts with the phenomenon of emerging nationalism. Rupnik (1996:44) outlines three primary causes for the return of nationalism to post-communist Europe, which include "the end of the Cold War and the transformation of the international system; the ideological vacuum after Communism; the economy, caught between globalism and the decomposition/ recomposition of systems". Many authors tackle the stereotypical depiction of the East in Western countries (e.g. Wolf, 1994), particularly the Balkans (e.g. Todorova, 1997) and the "return to Europe" phenomenon (more on this in: Skoko, 2016). Namely, owing to the bloody history of the region and the wars during and after the disintegration of Yugoslavia in the 1990s, the century-old stereotypes associated with the Balkans have come to life again and are still dominant in the collective memory of Europeans.

Dictionary definitions of "balkanize" tend to emphasize diversity, conflict and fractionalization (Todorova, 1994; Hall and Danta, 1996). It has therefore been one role of tourism marketing for destination countries on the fringe of South-Eastern Europe to distance themselves from "Balkanness" and to employ branding to this end (Hall, 2004:117).

The book International Public Relations - Perspectives from Deeply Divided Societies, edited by Ian Somerville, Owen Hargie, Maureen Taylor and Margalit Toledano (2017), also offers interesting analyses of the role of public relations in post-conflict societies such as those in the areas of the former Yugoslavia and Northern Ireland as well as in the relations between Israel and Palestine. In the chapter on Yugoslavia, they particularly address the "nation building and communication" phenomenon, focusing on Croatia during the EU accession period, and on Bosnia and Herzegovina, where there were a number of attempts made by the international community to improve the country's economic, political and social stability and strengthen its unity by using information and communication campaigns. They stress the role of communication in building a nation and national identity, but also a state brand.

According to the rather scarce literature dealing with state-branding attempts in the former Yugoslav countries, it seems that what all these newly created states have in common are their efforts to become major tourist brands. To this end, Slovenia and Croatia have made the greatest progress in creating their own brands. "In both cases, as recently emergent independent states formerly of the Yugoslav federation, their use of branding has positively attempted to assist the creation of a new national image, and negatively, to distance themselves from the Yugoslav past" (Hall, 2004: 117).

Slovenia is one example of a state that has succeeded admirably in shaking off the negative perception of being "Balkan" through successful promotion of branded exports (Elan skis, Gorenje appliances, Laško pivo beer and others), well-funded tourism campaigns, and by joining NATO and then the EU (Anholt, 2007:117). Slovenia's case is extraordinary in terms of its tourism industry and political sphere and it should be further explored within the context of nation branding and competitive identity development practices in new Europe (Poljanec-Borić, 2016:15). 
The book Evolution of Destination Planning and Strategy - The Rise of Tourism in Croatia, edited by Larry Dwyer, Renata Tomljenović and Sanda Čorak (2017), is dedicated to the phenomenon of tourism development in Croatia and the creation of a distinctive brand for that state - something the editors present as a successful example of tourism development: "In terms of tourism, Croatia is a rising star. Although occupying only $1.3 \%$ of EU territory, and accounting for less than $1 \%$ of the total EU population, it realizes 61 million of tourist nights or $5.1 \%$ of EU total. When the number of tourist nights is put in proportion to the population size, Croatia is the most popular destination in the European Union, alongside Malta and Cyprus" (Dwyer at al., 2017:1).

However, tourism is only one segment in creating a nation brand. Anholt (2007:26) believes that a national brand - or the Hexagon of Competitive Identity - is made up of tourism, brands, policy, investments, culture and people. Each of these segments contributes to the identity and image of a country, speaking of its strength, creativity, success, even charm. This is why this analysis will try to establish to what extent some countries are dedicated to these segments in the creation of their own brands and how they are perceived by the world.

Jaffe and Nebenzahl (2006:138) define country branding as using marketing strategies in order to promote the image, products and attractions of a particular country for attracting tourists and foreign investments. Most authors dealing with the country branding phenomenon agree that countries must become brands in order to achieve their political, commercial and other goals in the global market (cf. Skoko, 2009: 131). This is why every country that successfully manages its own identity and image - and its communication and promotion at a global level - protects itself from the effects of the so-called external branding (a risk of others creating its image in the international community). However, the entire process as such will not automatically make it a distinctive and appreciated brand, because a number of factors are required for it. For example, Dinnie (2010:15) defines nation brand as a unique, multidimensional blend of elements enabling the differentiation of a country on the basis of culture and relevance for its target audiences. Countries become brands in certain political and economic environments, competing with others with increasingly similar products and services and with similar communication and marketing strategies, techniques and tools at their disposal. This is why their identity comes into the picture, together with the special qualities and features that distinguish them from their environment and competition, as well as the ability and creativity they employ in their attempts to make their identity more competitive (Skoko, Gluvačević, 2016). This phenomenon is addressed in Simon Anholt's book Competitive Identity (2007), which sees the identity and special qualities of countries as branding trump cards in the globalized world. It is widely assumed that the tools and know- how related to commercial branding can be used to help any given country to develop a coherent and viable identity, attract foreign capital and motivate its citizens to adhere to the government's policies (Aronczyk, 2013: 3). Nation branders argue that smaller and poorer nations in particular need to work on developing their recognizable image in the global marketplace (Anholt, 2003, 2007; Holt, 2004; Kotler and Gertner, 2002; Olins, 1999; Papadopoulos and Heslop, 2002) in order to increase visibility, attract 
tourists and foreign investors, expand exports, promote their international profiles among members of international organizations, and, importantly, mobilize patriotism at home (Volčič, 2014:147).

\section{Brand perception and rankings of Slovenia, Croatia, Bosnia-Herzegovina and Serbia}

Because of the continued increase of the importance of destination branding, numerous institutions around the world have been trying to "measure" the strength or popularity - of individual countries as brands. As such, millions of people around the world have been using these rankings as a kind of guide for visits, investments, living, etc. Such rankings are popular and deemed trustworthy by the public; they can be used for additional promotion of individual countries as they are mostly based on extensive public opinion surveys and/or measurable economic indicators, or facts like natural diversity, state of cultural heritage, investments in tourism, investment climate, cordiality and hospitability of their people etc., while meeting with powerful response from the international public community at the same time. Despite their different methodological approaches, all of the leading nation-brand evaluation indexes are mostly focused on similar parameters (see more in: Skoko and Gluvačević, 2016). In order to establish the ratings of Slovenia, Croatia, BosniaHerzegovina and Serbia, we will focus on Future Brand: Country Brand Index, Bloom Consulting and Brand Finance ${ }^{1}$, due to its credibility in the public arena, its citation rates and its influence.

The Future Brand: Country Brand Index is based on the quantitative and qualitative methods used on a sample of between 2,500 and 3,600 public opinion makers who are also frequent visitors from 13 to 18 countries, depending on the year of the survey (Future Brand: Country Brand Index 2012-2013, 2012:5; Future Brand: Country Brand Index 2014-2015, 2014:8). Every country is assessed on the basis of the following criteria: value system, quality of life, business opportunities, tourism heritage \& culture, made in (product brands from that country). The purpose of the questionnaires used in the surveys is to find out how strongly the respondents perceive countries through seven different spheres: Awareness, Familiarity, Preference, Associations, Consideration, Decision/Visitation and Advocacy (Future Brand: Country Brand Index 2014-2015, 2014:8).

Brand Finance prepares financial assessments of a country's brand value, focusing on measurable economic categories such as national GDP trends, comparing values, strength of influential brands, assessing nation brand strength, weighing average cost of capital or discount rate, long-term growth rate and brand valuation (Brand Finance: Nation Brands, 2014:3). Bloom Consulting ranks countries using two criteria: country as a tourism brand and country as an economic brand. Bloom Consulting's methodology is based on assessments of six dimensions (for each of the 187

1 One of the leading indexes - Simon Anholt's Nation Brand Index - does not include the former Yugoslav countries in its surveys. 
countries observed): attraction of investment, attraction of tourism, attraction of talent, strengthening national pride (increase of national pride), strengthening public diplomacy and strengthening exports (Bloom Consulting, 2013:3-5).

Table 1

Future Brands - Country Brand Index

\begin{tabular}{|l|c|c|c|c|}
\hline & $\mathbf{2 0 1 0}$ & $\mathbf{2 0 1 1}$ & $\mathbf{2 0 1 2 / 2 0 1 3}$ & $\mathbf{2 0 1 4 / 2 0 1 5}$ \\
\hline Croatia & 49 & 40 & 41 & 44 \\
\hline Slovenia & 54 & 52 & 63 & $\mathrm{n} / \mathrm{a}$ \\
\hline Bosnia and Herzegovina & $\mathrm{n} / \mathrm{a}$ & $\mathrm{n} / \mathrm{a}$ & 82 & $\mathrm{n} / \mathrm{a}$ \\
\hline Serbia & 84 & 97 & 108 & $\mathrm{n} / \mathrm{a}$ \\
\hline
\end{tabular}

Sources: FutureBrand: Country Brand Index, p. 106; FutureBrand: Country Brand Index 2014-2015, p. 43

Future Brands index places Croatia on top according to the strength of its brand. In its 2014/2015 report, the Future Brands Country Brand Index ranks Croatia $44^{\text {th }}$ as the only former Yugoslav country; we can assume that other former Yugoslav countries did not make it in the TOP 75 list. Croatia is still considered a brand but, as we can see on page 36 of the report (http://www.futurebrand.com/uploads/CBI14 15-LR.pdf, downloaded on 13 February 2017), the chart shows that it gravitates toward the "experience countries" group more than toward the "status countries" or "brand countries" groups. This Index ranked Croatia 40 ${ }^{\text {th }}$ in 2011 and $49^{\text {th }}$ in 2010. Interestingly, however, Future Brand 2011 (2011-2012:53) ranked Croatia as the ninth country in the world according to its natural attractions, while not including it among the leading countries in any other category. On the one hand, it is positive that it recognized Croatia's natural attractions. On the other, the fact that Croatia as a tourist country failed to be put on the map for any other tourist advantage in the competitive environment can be considered a problem.

Table 2

Bloom Consulting index (2014/2015)

\begin{tabular}{|l|c|c|c|c|}
\hline & $\begin{array}{c}\text { Tourism - World } \\
\text { ranking }\end{array}$ & $\begin{array}{c}\text { Tourism - CBS } \\
\text { ranking }\end{array}$ & $\begin{array}{c}\text { Trade - World } \\
\text { ranking }\end{array}$ & $\begin{array}{c}\text { Trade - CBS } \\
\text { ranking }\end{array}$ \\
\hline Croatia & 28 & $\mathrm{~A}$ & 88 & $\mathrm{BBB}$ \\
\hline Slovenia & 55 & $\mathrm{AAA}$ & 139 & $\mathrm{BBB}$ \\
\hline Bosnia and Herzegovina & 133 & $\mathrm{~B}$ & 121 & $\mathrm{BBB}$ \\
\hline Serbia & 103 & $\mathrm{BB}$ & 91 & $\mathrm{BB}$ \\
\hline
\end{tabular}

Sources: Bloom Consulting - Country Brand Ranking Tourism Edition 2014/2015, pp. 21-22;

Bloom Consulting - Country Brand Ranking Trade Edition 2014/2015, p. 22

According to this ranking, Croatia and Slovenia have an attractive status as tourist countries. As for the investment and business criteria, the scores are rather devastating. In this respect, the rankings of Croatia and Serbia are somewhat higher than those of Bosnia-Herzegovina and Slovenia. 
Table 3

Country rankings according to Brand Finance

\begin{tabular}{|c|c|c|c|c|c|c|c|}
\hline & 2010 & 2011 & 2012 & 2013 & 2014 & 2015 & 2016 \\
\hline Croatia & $\begin{array}{c}53 \\
(\$ 25 \mathrm{~B}) \\
\text { Rating: BB }\end{array}$ & $\begin{array}{c}69 \\
(\$ 30 \mathrm{~B}) \\
+21,2 \% \\
\text { Rating: } \mathrm{BB}\end{array}$ & $\begin{array}{c}62 \\
(\$ 47 \mathrm{~B}) \\
+42.5 \% \\
\text { Rating: A- }\end{array}$ & $\begin{array}{c}66 \\
(\$ 40 \$) \\
-14 \% \\
\text { Rating: A }\end{array}$ & $\begin{array}{c}73 \\
(\$ 36 \mathrm{~B})-9 \% \\
\text { Rating: A }\end{array}$ & $\begin{array}{c}76 \\
(\$ 32 \mathrm{~B}) \\
-11 \% \\
\text { Rating: A }\end{array}$ & $\begin{array}{c}74 \\
\text { (\$33B) +4\% } \\
\text { Rating: A+ }\end{array}$ \\
\hline Slovenia & $\begin{array}{c}52 \\
(\$ 29 B) \\
\text { Rating: BBB }\end{array}$ & $\begin{array}{c}68 \\
(\$ 33 \mathrm{~B}) \\
+12.8 \% \\
\text { Rating: } \mathrm{BBB}\end{array}$ & $\begin{array}{c}59 \\
(\$ 50 \mathrm{~B}) \\
+39.7 \% \\
\text { Rating: A- }\end{array}$ & $\begin{array}{c}62 \\
(\$ 47 \mathrm{~B})-5 \% \\
\text { Rating: A }\end{array}$ & $\begin{array}{c}60 \\
(\$ 56 \mathrm{~B}) \\
+18 \% \\
\text { Rating: A- }\end{array}$ & $\begin{array}{c}62 \\
\text { (\$53B) }-5 \% \\
\text { Rating: A }\end{array}$ & $\begin{array}{c}61 \\
\text { (\$53B) } 0 \% \\
\text { Rating: AA- }\end{array}$ \\
\hline $\begin{array}{l}\text { Bosnia and } \\
\text { Herzegovina }\end{array}$ & $\mathrm{n} / \mathrm{a}$ & $\begin{array}{c}86 \\
(\$ 14 \mathrm{~B}) \\
\text { Rating: BBB }\end{array}$ & $\begin{array}{c}88 \\
(\$ 16 \mathrm{~B}) \\
+11.5 \% \\
\text { Rating: } \mathrm{BBB}\end{array}$ & $\begin{array}{c}90 \\
(\$ 12 \mathrm{~B}) \\
-21 \% \\
\text { Rating: BBB }\end{array}$ & $\begin{array}{c}89 \\
(\$ 15 \mathrm{~B}) \\
+19 \% \\
\text { Rating: BBB }\end{array}$ & $\mathrm{n} / \mathrm{a}$ & $\mathrm{n} / \mathrm{a}$ \\
\hline Serbia & $\mathrm{n} / \mathrm{a}$ & $\begin{array}{c}66 \\
(\$ 38 B) \\
\text { Rating: A- }\end{array}$ & $\begin{array}{c}69 \\
(\$ 40 \mathrm{~B})+ \\
10.7 \% \\
\text { Rating: } \mathrm{BBB}\end{array}$ & $\begin{array}{c}75 \\
(\$ 31 \mathrm{~B}) \\
-23 \% \\
\text { Rating: BBB }\end{array}$ & $\begin{array}{c}74 \\
(\$ 34 \mathrm{~B}) \\
+11 \% \\
\text { Rating: } \mathrm{BBB}\end{array}$ & $\begin{array}{c}78 \\
\text { (\$31B) }-9 \% \\
\text { Rating: A- }\end{array}$ & $\begin{array}{c}73 \\
\text { (\$33B) +9\% } \\
\text { Rating: A }\end{array}$ \\
\hline
\end{tabular}

Sources: Brand Finance Nation Brands 100, pp. 19, 67-68; Top 100 Nation Brands 2012, pp. 66-67; Brand Finance Nation Brands 2013, p. 21; Brand Finance Nation Brands 2014, p. 23; Brand Finance Nation Brands 2015, p. 15; Brand Finance Nation Brands 2016, p. 15.

The above table shows that all four countries rank lower on the country-brand scale compared to 2010, although the ratings of Croatia, Slovenia and Serbia have increased. As regards the overall country-brand value, only Slovenia has increased it, thus maintaining the status of the most expensive brand among these countries. The brand values of Croatia and Serbia at the end of 2016 were similar, although Croatia has a somewhat higher rating.

Countries of the former Yugoslavia focus their branding efforts on tourism for the sole purpose of attracting tourists. Therefore it is further interesting to analyze international tourist arrivals and receipts in countries of interest for our analysis in order to evaluate the success of their tourism branding efforts.

Table 4

International Tourist Arrivals 2010-2015 (number of tourists in millions)

\begin{tabular}{|l|c|c|c|c|c|c|}
\hline & $\mathbf{2 0 1 0}$ & $\mathbf{2 0 1 1}$ & $\mathbf{2 0 1 2}$ & $\mathbf{2 0 1 3}$ & $\mathbf{2 0 1 4}$ & $\mathbf{2 0 1 5}$ \\
\hline Croatia & 9,111 & 9,927 & 10,369 & 10,955 & 11,627 & 12,683 \\
\hline Slovenia & 1,869 & 2,037 & 2,156 & 2,259 & 2,411 & 2,707 \\
\hline Bosnia and Herzegovina & 0,365 & 0,392 & 0,439 & 0,529 & 0,536 & 0,678 \\
\hline Serbia & 0,683 & 0,764 & 0,810 & 0,922 & 1,029 & 1,132 \\
\hline Macedonia & 0,262 & 0,327 & 0,351 & 0,400 & 0,425 & 0,486 \\
\hline Montenegro & 1,088 & 1,201 & 1,264 & 1,324 & 1,350 & 1,560 \\
\hline Kosovo & $\mathrm{n} / \mathrm{a}$ & $\mathrm{n} / \mathrm{a}$ & $\mathrm{n} / \mathrm{a}$ & $\mathrm{n} / \mathrm{a}$ & $\mathrm{n} / \mathrm{a}$ & $\mathrm{n} / \mathrm{a}$ \\
\hline
\end{tabular}

Sources: UNWTO Tourism Highlights 2012, p. 7; UNWTO Tourism Highlights 2013, p. 8; UNWTO Tourism Highlights 2014, p. 8; UNWTO Tourism Highlights 2015, p.8; UNWTO Tourism Highlights 2015; p.8 and UNWTO Tourism Highlights 2016, p. 8. 
Table 5

International Tourism Receipts (mil. US\$) 2010-2015

\begin{tabular}{|l|c|c|c|c|c|c|}
\hline & $\mathbf{2 0 1 0}$ & $\mathbf{2 0 1 1}$ & $\mathbf{2 0 1 2}$ & $\mathbf{2 0 1 3}$ & $\mathbf{2 0 1 4}$ & $\mathbf{2 0 1 5}$ \\
\hline Croatia & 8,259 & 9.185 & 8,774 & 9,555 & 9,866 & 8,833 \\
\hline Slovenia & 2,566 & 2,708 & 2,577 & 2,791 & 2,719 & 2,504 \\
\hline Bosnia and Herzegovina & 0,594 & 0,628 & 0,603 & 0,689 & 0,707 & 0,656 \\
\hline Serbia & 0,798 & 0,992 & 0,906 & 1,053 & 1,139 & 1,048 \\
\hline Macedonia & 0,197 & 0,239 & 0,233 & 0,267 & 0,295 & 0,267 \\
\hline Montenegro & 0,660 & 0,777 & 0,826 & 0,884 & 0,906 & 0,902 \\
\hline Kosovo & $\mathrm{n} / \mathrm{a}$ & $\mathrm{n} / \mathrm{a}$ & $\mathrm{n} / \mathrm{a}$ & $\mathrm{n} / \mathrm{a}$ & $\mathrm{n} / \mathrm{a}$ & $\mathrm{n} / \mathrm{a}$ \\
\hline
\end{tabular}

Sources: UNWTO Tourism Highlights 2012, p. 7; UNWTO Tourism Highlights 2013, p. 8; UNWTO Tourism Highlights 2014, p. 8; UNWTO Tourism Highlights 2015, p.8; UNWTO Tourism Highlights 2015; p.8 and UNWTO Tourism Highlights 2016, p. 8.

Obviously, by those criteria Croatia is the most successful former Yugoslav republic. The fact that it is an Adriatic country with a beautiful coast and 1,244 islands has certainly contributed to this. However, despite the fact that Croatia's tourism industry is more developed than those of its neighbours, this does not automatically mean that Croatia is a brand and that the other countries have nothing to offer in that particular regard. On the contrary, tourism - while essential - is but a segment in the creation of a national brand.

\section{Comparative analysis of Croatian, Serbian, Bosnian-Herzegovinian and Slovenian (nation) branding efforts from 1990 to present}

\subsection{Croatia}

A new sovereign state on the map of Europe as of 1990 Croatia faced two major challenges. Similar to many other transition countries, Croatia suffered from an image forged during an earlier and very different political era, which constantly obstructed its political, economic, cultural and social aspirations. Therefore, in a relatively short period of time, it had to position itself on the international political stage and win the favour of the international community, while at the same time defending its territory against aggression. In such circumstances creating a recognisable image and one that would sway public opinion in Europe towards perceiving Croatia in a more positive light was simply not possible. But, it has to be pointed out, not for lack of trying. When the war in Croatia started most people in the world perceived the country, correctly, as a victim of aggression. But that perception, albeit casting Croatia as being on the side of the angels in the war, solidified its image abroad as an unsafe country. At the same time, Croatia was torn asunder by misinformation campaigns launched by structures vehemently opposed to its independence and by prejudices and stereotypes harking back to earlier conflicts. The complexity of the 
situation was simply too much for casual observers in the West to take in (Skoko, Miličević and Krešić, 2017:83).

The task for Croatia was clear enough; it needed to establish itself as a new country, not connected in any way, shape or form with the other republics of the former Yugoslavia. In order to achieve this Croatia focused on tourism and natural attractions as its key strategic advantages and its most recognizable features. It was both a strategic communication and political decision because Croatia launched its tourism promotion while the outcome of the war still hung in the balance. The Croatian Tourist Board, the agency in charge of the country's tourism promotion, started preparing for an international promotion campaign under the slogan 'Croatia - a small country for a great vacation'. Not surprisingly, the emphasis of the campaign was on Croatia's national beauty, pristine coast featuring one thousand islands, its rich cultural and historical heritage and its reputation, established over the past half-century, as a desirable travel destination. The goal was to show that Croatia possessed many advantages over its neighbours and ram home the fact that it was unique and separated culturally, socially and economically from the other republics of the former Yugoslavia.

Under these circumstances, it was vital, following the cessation of conflict, that Croatia should establish a national tourism marketing policy which, closely allied to national image rebuilding, would, as a brand, convey a distinct image (Hall, 2004):

- To differentiate clearly the country from its neighbours

- To reassure former markets that quality and value had been restored

- Through the country's major tourism attributes to secure long-term competitive advantage.

At that time the new marketing strategy was unveiled to the public. In collaboration with the McCann-Erickson communication agency a series of promotional posters were printed. In addition to that a tourist guide booklet in twelve different languages was published in a press run of 700 000. The tourist guide booklet presented Croatia as an attractive 'old' travel destination, 'revealing itself' to the world again. During 1993 and 1994, Croatia was 'portrayed' in two series of tourism posters, and 1994 saw the publication of the promotional booklet 'The Thousand Islands of the Croatian Adriatic' and 'Zagreb, The Heart of Croatia - The New European Metropolis' (Skoko, 2004).

In addition to this, the Croatian National Tourist Board (the umbrella government institution in charge of promoting Croatia's tourism industry) organized the advertising of Croatia as a tourism brand through leading global mass media outlets. As part of public relations, study trips to Croatia for foreign journalists were organized. Also, the National Tourist Board arranged participation of many Croatian private and public sector organisations in leading tourism and trade fairs throughout the world. The campaign was relentless and ultimately successful. Croatia was now perceived as an entity separate from the other republics of the former Yugoslavia and Croatia's tourism industry experienced a dramatic rate of growth and the upward trend continues to this day. The success of the campaign helped suppress negative associations with 
the war and accompanying developments, which were associated with Croatia in the early 1990s (Skoko, Miličević and Krešić, 2017:89).

Although the 1990s tourism promotion campaign yielded good results, it was clearly not enough, because Croatia was still rather unknown as a political, economic and cultural brand. Croatia officially started the process of its EU accession in 2003. It was the context in which the president at the time, Stjepan Mesić, appointed a special working group "for stimulating Croatia's long-term and integrated promotion in the European Union". The working group consisted of journalists, publicists, experts for public diplomacy, design, corporate identity, media and politics, and non-governmental organizations. They published their ideas in a special publication entitled Author's Notebook (Autorska bilježnica), proposing in it the elements of Croatia's new identity and suggestions for communication and promotional activities. It was not a strategic document; it merely offered ideas and suggestions that required shaping. One of the suggestions was to establish a separate government body tasked with the promotion of Croatia around the world. The working group's concrete suggestions triggered a heated debate in the Croatian public. However, almost none of its suggestions were adopted because of absence of any follow-up initiative, either by the president or the government.

In 2002 the Croatian National Tourist Board engaged the services of the consulting agency THR from Spain, which created a Strategic Marketing Plan for the promotion of Croatian tourism around the world, based on which a new wave of tourism promotion was launched under the slogan 'The Mediterranean as it once was'. In this way, Croatia sought to position itself as a Mediterranean travel destination, and simultaneously present itself as a country with a pristine natural environment. During those years Croatia established itself as a desirable Mediterranean travel destination and the period marked a significant increase in tourism activity. The Strategic Marketing Plan of Croatia's Tourism for the 2010-2014 period puts an emphasis on a new image of a destination based on experience and emotions. The Plan suggested the communication of simple elements of the country's identity - preserved coast, unique system of islands, intact hinterland and rich cultural heritage. The Plan defined the basic positioning of the brand of Croatia as a Mediterranean country which has preserved the heritage of its ancestors. Thus, in spite of the efforts to bring the continental Croatian landscapes closer to the world, the Mediterranean heritage is still at the root of how the brand is perceived. The latest communication concept defined by the Croatian National Tourist Board resulted with the new slogan for Croatian tourism promotion 'Croatia - Full of life'. The new slogan is a product of the marketing company BBDO and its subsidiaries from Croatia, Great Britain and Spain. It was developed in accordance with the Croatian Tourism Development Strategy until 2020 (Skoko, Miličević and Krešić, 2017:90).

During the last two decades, Croatia has successfully repositioned its image from newly formed Balkan state, burdened with the legacy of war, conflict and socialism - to a beautiful and attractive Mediterranean tourist destination. In some countries (especially in northern Europe) Croatia is still popularly perceived in terms of the horrors it experienced during the war and as a former republic of Communist Yugo- 
slavia. However, it is important to stress that over the past two decades the perception has altered significantly and it is a fact that most people in Europe see Croatia in a good light (Miličević et al., 2013:236). However, over these years, the Croatia's tourism promotion was Croatia's only organized and systematic international communication.

There is no doubt that Croatia's tourism promotion is an efficient channel of communication, but it has to be pointed out that its positive results should be followed up by other forms of strategic communication (public diplomacy, cultural promotion etc). Unfortunately, these avenues of promoting the country remain unused. Admittedly, the Ministry of Foreign and European Affairs (its public diplomacy segment), the Ministry of Culture (promotion of Croatian culture) and the Croatian Chamber of Economy (promotion of Croatian products) do assist the Croatian Tourist Board in the promotion of Croatian culture throughout the world, but these projects are sporadic. Also, the efforts of the mentioned institutions are mostly uncoordinated. An integral national strategy for country-brand management is missing, too.

Despite the several symposiums and conferences dedicated to the importance and necessity of a coherent strategic branding of the country and the fact that several prime ministers (between 2013 and 2016) underlined the importance of integral country-branding, political institutions have neither expressed any serious interest nor have they undertaken adequate steps yet. While it has managed to become a tourist brand, Croatia has failed to create an adequate recognisability in other spheres. Indeed, it has even failed to adequately take advantage of its membership in the EU in order to present itself better to its European neighbours.

\subsection{Serbia}

Since the ousting of Slobodan Milošević from power in 2000, Serbia has made various efforts to transform the country's negative image, acquired during the political turmoil of the 1990s, into a positive one, imbued with hope, optimism, and opportunities. Although the idea of national rebranding was discussed in Serbian media from the start of the new millennium, constructing a new image posed a greater challenge for Serbia than for most other post-communist countries. In addition to the wars of the 1990s, Serbia's image was affected by worldwide media coverage of the Hague trials, the assassination of the prime minister in 2003, Kosovo's independence and the related protests, and recent violence against foreigners at sports events (Mijatović, 2012:213).

Hall (2002) argues that, in Serbia in the 1990s, ethnic identity was used as a tool for the search of the nation's identity and often for political purposes. Serbia's historic heritage served as the main source and bedrock of Serbia's forgotten identity. After Milošević - who had launched a campaign of illegitimate historical revision in order to justify Serbia's military aggression against its neighbours - fell from power, the new democratic government started re-establishing Serbia's reputation internationally. In the early 2000s, the new state administration made significant efforts to im- 
prove Serbia's image and position among the Western countries and attract foreign investments (Hall, 2002).

However, it was not until 2006 - when Serbia declared its independence after Montenegro had left the joint state - that concrete activities were undertaken. Like the other former Yugoslav countries, Serbia then faced the challenges of positioning itself as a nation and improving its image and reputation. But the path to that new, independent Serbia had been marked with dynamic historical, political and economic changes, civil war, international economic sanctions and NATO bombardment - all of them substantially contributing to the creation of a negative picture of Serbia and its "bad guy" image (Torres, 2008; Nation branding, 2009; Kaneva, 2012:213, as cited in: Novčić and Štavljanin, 2015:266). At the initiative of the Serbian government, the Council for Promotion of Serbia (also known as the Council for Branding of Serbia) was formed in late 2006. The Council's primary purpose was to create the National Strategy for the Promotion of Serbia, which was to be adopted later by the Serbian government (Novčić and Štavljanin, 2015:266). A year later, Milka Forcan, a prominent manager, was appointed as the chairperson of the council. Its members included renowned experts from various fields. They were supposed to carry out the research and analyses required for the positioning of Serbia's brand, develop a strategy geared towards that goal and create an Internet website for Serbia's promotion. However, the Council was embroiled in numerous controversies and was extensively criticised by the media and politicians. After a series of such attacks, Ms. Forcan stepped down from the position of chairperson and was replaced by the director of Belgrade Philharmonic Orchestra, Ivan Tasovac (Politika.rs, 21.8.2009). The project suffered from poor communication efforts and inadequately defined goals and the public greeted it with disdain. As a result, the Council was disbanded soon afterwards (Novčić and Štavljanin, 2015:266).

An international competition for participation in the development of the "Strategy for Branding and Promotion of Serbia" was announced. The strategy was drafted by the Ministry of International Economic Relations and Ministry of Trade, Tourism and Services. It aimed to change the negative image of Serbia abroad, specifying four goals: foreign investment, exports, tourism and foreign policy. The competition was announced with international communication agencies in mind. They were supposed to "develop a complete action plan for establishing a name for "Made in Serbia" products and the country's tourism supply and for improving it political image in the world". The Ministry of International Economic Relations provided the budget of EUR 1 million for the development of the strategy, and eight international marketing companies submitted their proposals (according to www.b92.net). However, the outcome of the competition is unknown. Novčić and Štavljanin (2015:267) attempted to learn the reasons for the branding strategy's failure: its misunderstood concept, inadequate focus, complexity, large number of stakeholders and absence of a clear model. Serbia is still dealing with the aftermath of the political situation of the 1990s, with political corruption, economic inequalities, and rebuilding of the infrastructure destroyed during the preceding decade (Mijatović, 2014:228). In the opinion of Vranješ, Jovičić and Gašević (2014:60), when rebranding itself, Serbia should not aim at polishing its negative image from the past; it should do the op- 
posite instead - identify its crucial specific advantages and use them as the base for the campaign.

After the failure of the Council's initiative, the overall promotional activities have been reduced to tourism promotion carried out by the National Tourism Organization of Serbia. Also, as a reminder of the importance of Serbia's branding, annual conferences on branding take place regularly, with the participation of renowned world experts. In the meantime, individuals like tennis player Novak Đoković and events like the Eurosong Contest, the Universiade, musical festivals like Exit and Guča have also contributed to Serbia's visibility (Mijatović, 2012; Vranješ, Jovičić and Gašević, 2014). While Croatia has been focused on its tourism promotion and on branding itself as a tourist destination - never even having tried to implement a comprehensive country-branding project, Serbia has at least made efforts to that end. On the other hand, its tourism branding efforts have not been efficient enough.

\subsection{Bosnia and Herzegovina}

Independent Bosnia and Herzegovina, as a former Yugoslav republic that has experienced a bloody and devastating war (1992 - 1995) and some twenty years of instability and political crises, is also trying to become a brand among the countries of the modern world. However, unlike Slovenia and Croatia, which have developed into stable democracies in the few past years, Bosnia and Herzegovina is still an unstable country and a divided multiethnic society. "The Bosniaks, Croats and Serbs still have not reached the minimal consensus on the fundamental values and standards of their coexistence - a necessary basis for the establishment and functioning of a democratic political order" (Kasapović, 2005:15-16).

In order to turn Bosnia and Herzegovina into a stable and functional state, the international community has invested large amounts of money into its reconstruction and into various information and communication campaigns aiming at the renewal of trust and strengthening of the state institutions (Somerville, Hargie, Taylor and Toledano, 2017:14). Public relations played many roles in post-war Bosnia. The oneway communication tactics of media relations, public information, nation branding and publicity have dominated (Somerville, Hargie, Taylor and Toledano, 2017:16). Unfortunately, many of these communication attempts failed to bear fruit because the communicators ignored the big picture and real problems of the society of Bosnia and Herzegovina.

David MacDonald (2010:376) claims it was the unhealed traumas from the past that helped create, in the late 1980s, an emotional climate that encouraged negative myths and the readiness to believe in them are the causes of the bloody disintegration of Yugoslavia. Bosnia and Herzegovina is plagued by the same ethnic problems that caused the war in 1991. The situation today is somewhat more complex and correspondingly more dangerous because the traumas suffered during the war remain unresolved. It is within the realm of possibility that another war in Bosnia and Herzegovina will break out if the Serbs, Croats and Muslims in Bosnia and Herzegovina re- 
fuse to come to terms with their recent past. In that sense, it is important to prosecute those responsible for war crimes and crimes against humanity in order to reassure the citizens of Bosnia and Herzegovina that the rule of law can and will address the issues of the past and protect them in the future. On the other hand, the international representatives creating the future of this country should keep in mind the views and feelings of its citizens if they really want to succeed in their mission. This is why the branding process is important in this particular context: it forces the citizens of Bosnia and Herzegovina to question their own identity and understand that all three constitutive nations have common interests. However, despite the international community's efforts to help the country overcome its divisions and differences, ethnic tensions are still present, there is very little cooperation between the three nations, and the political discourse is marred by different interpretations of the past and conflicting ideas about the future. It is therefore only logical to conclude that it will be very difficult to implement the long announced constitutional amendments and reforms. The situation is simply two complex and rooted in mistrust and misunderstanding between the three nations. Any would-be reformer has to be acutely aware of the underlying tensions and perceptions that shape the country's political, social and economic woes. Otherwise, any attempt at reform is doomed to failure.

This is why Friedrich Ebert Stiftung, a German political foundation active in Bosnia and Herzegovina, carried out a number of surveys ${ }^{2}$ between 2010 and 2016, in order to establish the mutual perception of the three ethnic groups, their attitude toward the state and its identity, the image of Bosnia and Herzegovina in neighbouring countries, and the possibilities of branding in the absence of a consensus on crucial issues. Based on the survey results, a debate was organized with leading Bosnia and Herzegovina's experts from various fields and with international experts, in order to define the identity potentials of Bosnia and Herzegovina that could help the country become better known globally and start the branding process. A consensus was thus achieved between the experts and citizens that Bosnia and Herzegovina's trump cards for the creation of a new identity and international repositioning of the country should be: the mentality of its people, hospitability and straightforwardness, and natural attractions and diversity. Some citizens of Bosnia and Herzegovina see the following as the country's major assets: multicultural character, meeting point between various religions and cultures, meeting point between East and West. Also, they think that only economic stability can bring all three ethnic groups together and that economic stability can be achieved only if the three ethnic groups cooperate closely. Business cooperation will then spark cultural cooperation and the country will embark on a journey towards a brighter future. In the neighbouring countries, Bosnia and Herzegovina is known primarily for the war and its aftermath, and only then for its cuisine and unique lifestyle. Globally, it is either unknown or connected with the war, ethnic strife and poor functioning. ${ }^{3}$ The experts who took part in the

$\mathbf{2}$ The author of this paper led the survey project. The results can be found on the foundation's website - $\underline{\text { www.fes.ba }}$

3 More on this in: Skoko, B. (2015). Strateške smjernice za brendiranje Bosne i Hercegovine, Sarajevo: Friedrich Ebert Stiftung. 
survey project argue that a change of the image of Bosnia and Herzegovina in the world would be hard to expect without substantial reforms and changes on the ground. This implies serious reforms of political institutions, changes in election legislation, territorial reorganization, functioning of the government, changes in the mentality and in the attitude toward the country, development of economy, higher-quality tourism offerings and better infrastructure. However, the document also gives a list of the numerous attractions, events, destinations, cultural sights and historical figures in Bosnia and Herzegovina, on which a consensus has been achieved and which could be used for the country's promotion in the world. Surprisingly, the survey made it clear that this post-conflict state contains recognizable common elements that all three ethnic groups are proud of. These are good foundations for possible branding activities. Although the project was introduced to the public and in 2015 - to Mladen Ivanić, chairman of the presidency of Bosnia and Herzegovina - the authorities have not taken any action to this end.

Bosnia and Herzegovina started the process of branding itself as a travel destination in 2008 with the support of USAID and the Swedish International Development Agency (SIDA). The slogan "Enjoy life" has been adopted, a logo has been designed and a Brand Book with instructions has been published. However, systematic tourism promotional activities and the unique visual identity have become a reality only in some parts of the country. The additional problem the branding of Bosnia and Herzegovina is facing is the negative image of the Balkans in general. "Positioned on the western edge of the Islamic world, the Balkans, a term loosely conterminous with South-eastern Europe, is a region that has been subject in recent history to largely pejorative image constructions in the West" (Hall, 2004:117). However, in spite of everything, the country's urban centres, like Sarajevo or Mostar for example, are attracting a growing number of visitors. Međugorje - known by the alleged appearances of the Virgin Mary - has become a place of pilgrimage, attracting approx. two million pilgrims and tourists every year.

\subsection{Slovenia}

Within the mentioned transitional context of new European countries, Slovenia stands as one of the countries that had put brand management efforts ahead of all the other transitional policies and had started complex brand management activities prior to becoming an independent state (Poljanec-Borić, 2016:5). In terms of nation branding, Slovenia has done more than any other former Yugoslav country. It made its first such attempts while it was still a Yugoslav republic, often triggering sharp political reactions of the federal government at the time.

There were several attempts during the mid-1980s and early 1990s by the Slovenian Ministry of Tourism to engage in comprehensive nation branding and recast Slovenia's (international) image. It was as early as 1986 that the Slovenian Tourist Board created its first campaign "Slovenia - my country" (Slovenija - moja dežela). Later, the slogan "We are the people for tourism" (Turizem smo ljudje) was introduced, followed by "Slovenia, on the sunny side of the Alps" (Slovenija na soncni strani 
Alp). Other efforts included campaigns and slogans, running from 1995 to 2004, such us "A miniature Europe", "Paradise in Europe", "The green piece of Europe" and "Green jewel of Europe". In 1996, the Center for the Promotion of Tourism introduced a new logo to promote tourism in Slovenia - a bouquet of flowers referred to as a "bouquet of peace, greens, and love" that appeared alongside the word "Slovenia" spelled with the internal letters "love" bolded: SLOVEnia (Volčič, 2002:50).

To summarize, in the 1990s, Slovenia tried to create its new identity in various way in its attempts to present itself to the world as a new brand. Although the focus was primarily on tourism promotion, the ideas of other brand aspects that could tell Slovenia's tale were also considered in those early days. The country's accession to the European Union in 2004 gave an additional impetus to these efforts. A campaign with the slogan "Slovenia invigorates" was launched at that time, targeting the country's new European neighbours. In 2006, a global campaign under the slogan "Slovenia: your perfect getaway" was launched through global media outlets such as CNN, marking the country's efforts to promote itself not just as a tourist destination, but also as an ideal place for living, doing business and the like. Publications regarding the subject provide information on a few other campaigns, but also on the controversies accompanying them, such as criticisms of the poor choice of slogans etc.

Mostly, these campaigns were conscious attempts to detach Slovenia from the former Yugoslav, the "Balkan" region and what it dominantly stands for- backwardness and instability. The campaigns' goal is to reinforce the idea that Slovenia is historically and culturally a part of Western and "civilised" Europe by emphasizing the country's Habsburg heritage, Alpine character, and contiguity with Austria and Italy (Volčič, 2014:152).

Slovenia's latest branding initiative coincided with the country's presidency of the EU. In February 2007, just before Slovenia started its presidency, the Ministry of Economy unveiled a new branding campaign: first internally to the rest of the Slovenian government and then to the Slovenian public. Before then, Slovenia had not had a coordinated national brand, but national elites had been devoted to creating one for several years (Volčič, 2014:153). A new slogan, "I feel Slovenia", was thus chosen from hundreds of suggested ones. It was created by the Nuit marketing agency $^{4}$. The public and media reacted negatively to the selection because members of the jury had been politicians, not experts. Some people also claimed the competition had been rigged (Volčič, 2014:154). However, with time, the slogan proved to be quite successful. "I feel Slovenia" is the Slovenian national brand, representing Slovenia at home and abroad with a view to increase its recognition abroad and improve its symbolic position and influence in the international sphere. The administrator of the brand is the Government Communication Office. ${ }^{5}$

After the slogan had been chosen, tenders from communication agencies were invited for designing the overall nation branding project for Slovenia. The Pristop

$4 \underline{\text { http://www.nuit.si/portfolio-item/i-feel-slovenia/ }}$

5 http://www.ukom.gov.si/en/promotion of slovenia/ 
agency $^{6}$ got the job and came up with a new identity and desired image of the country based on extensive research and their own branding model, developed in cooperation with French expert Leslie de Chernatony. Pristop prepared a brand book, available to the public ${ }^{7}$, defining in detail the elements of Slovenia's identity and modes of communicating Slovenia as a brand, as well as its politics, economy, tourism, art and culture, science and sports. The role of the colour green ("Slovenia Green") and affinity towards nature ("The mission is clear: Forward with nature") are particularly emphasized. The book also proclaims: "Organic development is at the core of our vision". The Brand Book thus serves as a high-quality basis for every promotional communication and presentation of Slovenia in the world. In order to be applicable all across the board, it contains practical recommendations for using visual elements, photographs, logotypes etc.

A campaign targeting domestic and foreign audiences was organized in 2008. The events, presentations and advertising that it included were all carried out in accordance with this new identity of Slovenia. Although some critics point at the similarities of this approach with the ones of other "green" countries such as New Zealand, Ireland or Norway, it is nevertheless a big step forward for the countries of the former Yugoslavia because it is an attempt to create an integrated national brand on the basis of the data gleaned from various analyses and researches and other activities conducted by professionals and experts.

With the slogan "I feel Slovenia" serving as the national brand slogan, Slovenia has continued with its practice of using separate promotional campaigns. For example, the ongoing campaign is using the slogan "Slovenia - the hidden treasure of Europe". 8

\section{Conclusion}

When it comes to country branding, the above analysis shows similar goals and efforts, but completely different approaches, executions and models. The post-independence efforts of both Croatia and Slovenia have focused on emphasising their essentially western character as opposed to that of their eastern neighbours and on attempting to disassociate themselves from any and all Yugoslav connotations. In doing so, both countries have been using their natural attractions and advantages as trump cards in presenting themselves to the world.

In the meantime, Slovenia made progress toward an integrated national brand, while Croatia remained focused only on tourism. After a series of good practices and staying in the sphere of tourism branding, Slovenia made a strategic breakthrough in

6 www.pristop.si

${ }^{7}$ http://www.ukom.gov.si/fileadmin/ukom.gov.si/pageuploads/dokumenti/arhiv projektov/ IFS/Slovenias_Brand_brand_book.PDF.PDF

8

http://www.ukom.gov.si/en/promotion of slovenia/multimedia/powerpoint/ 
2007 when it approached branding in a professional way, laying the groundwork for future high-quality international communication. However, this high-quality strategy has not yet been accompanied by the strengthening of the strategic communication at all levels; consequently, no positive results have been achieved so far.

We have seen that Slovenia is much more experienced in branding efforts - they go way back to the days of former Yugoslavia - and its promotional efforts have created an added value in its economy and tourism. Croatia, on the other hand, has become a popular travel destination because of its natural attractions and the related promotional efforts. This is why the promotional campaigns have been one of its major economic tools. Also, Croatia has been forced to keep using new approaches and creativity when communicating its tourism offerings so as not to lag behind its competitors. Unfortunately, even after 25 years of independence, tourism has remained the single sphere of Croatia's international communication, which is a devastating fact. With the exception of a single (failed) attempt, Croatian authorities have shown no understanding for the overall branding of the country. Serbia, on the other hand, has understood the importance of branding, but has failed to carry out its plan due to lack of understanding in the public and the inadequacy of institutions and their lack of professionalism.

Both in Croatia and in Serbia, the first step in the branding process was to form working groups and a council, respectively. In doing so, Serbia went a little further in the strategic design of its activities. Having surpassed this level, Slovenia organized a successful call for proposals and hired professional agencies and branding experts. However, in none of these countries is there a state institution in place that would carry out and/or control the country identity and image management something that is found in numerous successful countries of the world. In Croatia and Serbia, promotion depends on the national tourism organizations; Slovenia has a government office in charge of it.

Lagging far behind is Bosnia and Herzegovina. All the initiatives and branding efforts mostly come from outside its borders - from international institutions or foreign NGOs as their contribution to the country's stabilization and development. Although the potentials have been identified, almost nothing has been done by the government institutions.

Since a branding process begins with the defining of a country's own identity, we have seen numerous mistakes and disorientation in these countries. Serbia searched for the foundations of its identity in myths from the past. Both Croatia and Serbia tried to find them in their attempts to "return to Europe" (where they have belonged for centuries), but Europe did not welcome them with open arms after the disintegration of Yugoslavia. As for Bosnia and Herzegovina, it still has three separate ethnic identities instead of a single, supranational identity. On the other hand, if we analyze their approaches to strategic communication, we can see that, for years, all four countries were content with sporadic successes and partial communication and promotional projects instead of striving for long-term goals and strategies. 
Differences in their approaches to international communication and branding can also be seen if we analyze the official government websites the individual countries use to present themselves to the world. Croatia uses two websites for its communication: croatia.hr, which is also the official website of the Croatian Tourist Board, and croatia.eu, which publishes information and interesting facts about Croatia (its history, people, culture, politics, society, lifestyle...). Its homepage contains news from Croatia's tourism offerings and the second page is very static: it does not cover current affairs in the country and is, in general, poorly positioned on the major search engines. Slovenia communicates via its official website slovenia.si, which offers information on the country, its tourism offerings, study programs, investments, employment and cultural offerings. In terms of layout and contents, the website is comparable to those of western European countries (the Swedish portal sweden.se is a good example). The visual elements and contents of the portal are in harmony with all other websites of the government and its ministries. The information about Slovenia's promotional activities is consolidated on the website of the Government Communication Office. ${ }^{9}$ Serbia mostly communicates via Serbia.travel portal - the official portal of the National Tourism Organization of Serbia, which presents the country's tourism offerings and its special qualities. Bosnia and Herzegovina communicates its tourism offerings to the world via bhtourism.ba - the portal of the Tourism Association of Federation Bosnia and Herzegovina, which, in fact, functions as the tourism organization of only one half of the country. The latter fact indicates the inability of the country's two entities to reach a consensus on the national level.

Consequently, while being aware of the need for international communication and branding, all the countries of the former Yugoslavia still do not meet the usual standards of strategic communication and branding when it comes to execution on a strategic level. They are focused on tourism promotion. None of the four analyzed countries have a systematic approach to managing its own identity and image, or brand (Slovenia ranks first in terms of integrated branding, and Croatia is the best when it comes to tourism branding). In most of these countries, the branding processes have been significantly hindered by unresolved political issues or the political elites' and public's failure to understand them.

\section{References}

1. Anholt, S. (2007). Competitive Identity, The New Brand Management for Nations, Cities and Regions. New York: Palgrave Macmillan.

2. Aronczyk, M. (2013). Branding the Nation, The Global Business of National Identity. Oxford: University Press.

3. Bilandžić, D. (2000). Naslijeđe prošlosti $i$ budućnost odnosa južnoslavenskih naroda i država, u: Fleck, Hans-Georg i Graovac, Igor (Ed.). Dijalog povjesničara - istoričara 2, Zagreb: Zaklada Friedrich Naumann, 43-60.

4. Dinnie, K. (2008). Nation Branding - Concepts, Issues, Practice. Oxford: Butterworth-Heinemann - Elsevier.

9 http://www.ukom.gov.si/en/promotion of slovenia/ 
5. Dwyer, L.; Tomljenović, R. and Čorak, S. (2017). Evolution of Destination Planning and Strategy - The Rise of Tourism in Croatia. Palgrave Macmillan.

6. Hall, D. (2004). Branding and national identity: the case of Central and Eastern Europe, in: Morgan, N.; Pritchard A. and Pride, R. (Eds.). Destination Branding: Creating the Unique Destination Proposition. Oxford: Elsevier ButterworthHeinemann. 111-127.

7. Hall, D. (2002). Brand development, tourism and national identity: The re-imaging of former Yugoslavia, Brand Management, 9 (4-5): 323-334.

8. Jaffe, D. E. and Nebenzahl, D. I. (2006). Nation Image \& Competitive Advantage. Copenhagen Business School Press.

9. Jović, D. (2003). Jugoslavija - država koja je odumrla. Zagreb: Prometej.

10. Kaneva, N. (2012). Branding Post-Communist Nations: Marketizing National Identities in the "New" Europe. Routledge.

11. Kasapović, M. (2005). Bosna $i$ Hercegovina podijeljeno drustvo $i$ nestabilna država. Zagreb: Politička kultura.

12. Mijatović, B. (2014). The Musical (Re)branding of Serbia: Srbija Sounds Global, Guča and EXIT, in: Kaneva, N. (Ed.). Branding Post-Communist Nations: Marketizing National Identities in the "New" Europe. Routledge.

13. Miličević, K.; Skoko, B. and Krešić, D. (2012). The Power of Tourism in Creating a National Brand: The Case of Croatia. Proceedings of the Destination Branding \& Marketing IV. Cardiff, 236-247.

14. Novčić, B. and Štavljanin, V. (2015). Brendiranje nacije: Analiza brend identiteta Srbije, Marketing, 46 (4): 263-276.

15. Poljanec - Borić, S. (2016). Destination Brand Management for the Support of Political Identity: The Case of Slovenia. Sociologija i prostor, 54/204 (1): 3-18.

16. Rupnik, J. (1996). The reawakening of European nationalism. Social Research, 63 (1): 41-75.

17. Silber, L. and Little, A. (1997). Yugoslavia - Death of a Nation. New York: Penguin Books.

18. Saunders, R. (2014). The Impact of Alternative Narrators on Nation Branding in the Former Second World, in: Kaneva, N. (Ed.). Branding Post-Communist Nations: Marketizing National Identities in the "New" Europe. Routledge.

19. Skoko, B.; Miličević, K. and Krešić, D. (2017). The Influence of Political Factor in Fashioning Destination Image, in: Dwyer, L.; Tomljenović, R. and Čorak, S. (Eds.). Evolution of Destination Planning and Strategy - The Rise of Tourism in Croatia. Palgrave Macmillan, 79-97.

20. Skoko, B. (2015). Strateške smjernice za brendiranje Bosne i Hercegovine. Sarajevo: Friedrich Ebert Stiftung.

21. Skoko, B. (2004). Hrvatska - identitet, image i promocija. Zagreb: Školska knjiga.

22. Skoko, B. (2010). Hrvatska i susjedi - Kako Hrvatsku doživljavaju u Bosni i Hercegovini, Crnoj Gori, Makedoniji, Sloveniji i Srbiji. Zagreb: AGM.

23. Skoko, B. (2009). Država kao brend. Zagreb: Matica hrvatska.

24. Skoko, B. i Gluvačević, D. (2016). Države kao turistički brendovi: kreiranje, upravljanje i vrednovanje. Medijske studije, 7 (13): 78-101.

25. Somerville, I.; Hargie, O.; Taylor, M.; Toledano, M. (2017). International Public Relations - Perspectives from deeply divided societies. Routledge. 
26. Steindorff, L. (2006). Povijest Hrvatske - od srednjeg vijeka do danas, Zagreb: Jesenski \& Turk, Institut društvenih znanosti Ivo Pilar.

27. Szondy, G. (2006). The role and challenges of country branding in transition countries: The Central and Eastern European experience. Place Branding and Public Diplomacy, 3 (1): 8-20.

28. Todorova, M. (1997.): Imagining the Balkans. New York: Oxford University Press.

29. Volčič, Z. (2014). Branding Slovenia - „You Can’t Spell Slovenia Without Love...", in: Kaneva, N. (Ed.). Branding Post-Communist Nations: Marketizing National Identities in the "New" Europe. Routledge, 147-167.

30. Vranješ, M.; Jovičić, D. i Gašević, D. (2014). Brendiranje zemlje kao turističke destinacije - studija slučaja: Srbija. Ekonomija - teorija i praksa, 7 (4): 50-65.

31. Vurušić, V. (2008). Gdje smo nakon 16 godina. Jutarnji list, Magazin, 12. siječnja 2008, 66.

32. Wolff, L. (1994). Inventing Eastern Europe: The map of civilisation on the mind of the Enlightenment. Stanford University Press.

\section{Internet sources}

1. Bloom Consulting - Country Brand Ranking Trade Edition 2014/2015, http:// www.bloom-consulting.com/pdf/rankings/Bloom Consulting Country Brand Ranking_Trade.pdf, 14 February 2017.

2. Bloom Consulting - Country Brand Ranking Tourism Edition 2014/2015, http:// www.bloom-consulting.com/pdf/rankings/Bloom Consulting Country Brand Ranking_Tourism.pdf, 14 February 2017.

3. Brand Finance Nation Brands 100, http://brandfinance.com/images/upload/ bfnb 1002011 web sp.pdf, 10 February 2017.

4. Brand Finance Top 100 Nation Brands 2012, http://brandfinance.com/images/ upload/bfj nation brands 1002012 dp.pdf, 10 February 2017.

5. Brand Finance Nation Brands 2013, http://brandfinance.com/images/upload/ brand_finance_nation_brands_2013.pdf, 10 February 2017

6. Brand Finance Nation Brands 2014, http://brandfinance.com/images/upload/ brand finance nation brands report 2014 final edition.pdf, 10 February 2017.

7. Brand Finance Nation Brands 2015, http://brandfinance.com/images/upload/ nation brands 2015 for print.pdf, 11 February 2017.

8. Brand Finance Nation Brands 2016, http://brandfinance.com/images/upload/ nation_brands_2016_report.pdf, 11 February 2017.

9. Future Brands Country Brand Index 2012-2013, https://mouriz.files.wordpress. com/2013/02/cbi-futurebrand-2012-13.pdf, 13 February 2017.

10. Future Brands Country Brand Index 2014-2015, http://www.futurebrand.com/ uploads/CBI-14 15-LR.pdf, 13 February 2017.

11. Nuit, http://www.nuit.si/portfolio-item/i-feel-slovenia/, 24 April 2017.

12. Slovenia's Brand Book, http://www.ukom.gov.si/fileadmin/ukom.gov.si/pageuploads/dokumenti/arhiv projektov/IFS/Slovenias Brand brand book.PDF. PDF, 26 February 2016.

13. „Slovenia - The hidden treasure of Europe“ campaign 
14. http://www.ukom.gov.si/en/promotion_of_slovenia/multimedia/powerpoint/, 21 February 2017.

15. UNWTO Tourism Highlights 2012, http://www.e-unwto.org/doi/ pdf/10.18111/9789284414666, 14 February 2017.

16. UNWTO Tourism Highlights 2013, http://www.e-unwto.org/doi/ pdf/10.18111/9789284415427, 14 February 2017.

17. UNWTO Tourism Highlights 2014: http://www.e-unwto.org/doi/ pdf/10.18111/9789284416226, 14 February 2017.

18. UNWTO Tourism Highlights 2015: http://www.e-unwto.org/doi/ pdf/10.18111/9789284416899, 14 February 2017.

19. UNWTO Tourism Highlights 2016: http://www.e-unwto.org/doi/ pdf/10.18111/9789284418145, 14 February 2017. 
Pregledni rad

\title{
Božo Skoko
}

Sveučilište u Zagrebu, Fakultet političkih znanosti, Hrvatska

e-mail:bozo.skoko@fpzg.hr

\section{Pogled na komunikacijske strategije i pokušaje brendiranja u odabranim zemljama nastalima nakon raspada Jugoslavije}

\begin{abstract}
Sažetak
Članak analizira pokušaje četiriju država nastalih raspadom bivše Jugoslavije - Hrvatske, Slovenije, Bosne i Hercegovine te Srbije na području brendiranja, odnosno korištenja komunikacijskih alata u vlastitom pozicioniranju kao turističkih destinacija te atraktivnih brendova na međunarodnom političkom i gospodarskom tržištu. U fokusu su komunikacijske i promotivne strategije koje su pritom korištene. Uspjeh pojedine zemlje na tom području ocijenjen je prema rangu koji su tim zemljama dodijelili najpoznatiji međunarodni indeksi posvećeni snazi država brendova. Članak također analizira različite pristupe i modele koje su koristile novonastale države u međunarodnom pozicioniranju i razvoju svojih brendova. Istraživanje je pokazalo kako su sve analizirane države koncentrirane uglavnom na promociju turizma, dok su ostali aspekti brendiranja zanemareni. Nijedna od zemalja nema razvijenu cjelovitu strategiju brendiranja niti sustavno strateški upravlja vlastitim identitetom i imidžom. Sputavaju ih neriješeni politički prijepori ili nesposobnost političara i građana da shvate prednosti i važnost brendiranja zemlje. Prema kriterijima korištenima u analizi, Slovenija je provela najcjelovitiji pokušaj brendiranja, dok je Hrvatska ipak vodeća u turističkom brendiranju. Rezultat analize sugerira da važnost brendiranja zemlje u ovom dijelu Europe nije u potpunosti osviješten te da ne postoji cjelovit pristup konceptu brendiranja, već samo sporadični pokušaji u svim četirima analiziranim državama.
\end{abstract}

Ključne riječi: zemlja, brendiranje, komunikacija s javnošću, Hrvatska, Slovenija, Bosna i Hercegovina, Srbija. 